\title{
HUBUNGAN ANTARA KECEPATAN LARI DAN KEKUATAN OTOT TUNGKAI DENGAN HASIL LOMPAT JAUH PADA SISWA PUTRA KELAS ATAS SD NEGERI 3 SIGLI TAHUN PELAJARAN 2018/2019
}

\author{
M. Yahya ${ }^{(1)}$, Muhammad $^{(2)}$ \\ ${ }^{1,2}$ Program Studi Penjaskesrek, Fakultas Keguruan dan Ilmu Pendidikan, \\ Universitas Jabal Ghafur
}

\begin{abstract}
ABSTRAK
Penelitian ini dilakukan berawal dari kesalahan-kesalahan yang dilakukan siswa putra kelas atas SD Negeri 3 Sigli pada saat pembelajaran lompat jauh. Kesalahan-kesalahan tersebut meliputi: (1) awalan, pada saat melakukan awalan tidak dilakukan dengan kecepatan yang cukup tinggi, dan tidak dapat mengontrol posisi tubuh, sehingga mengalami kesulitan dalam melakukan tumpuan, (2) tolakan, pada saat melakukan tolakan tidak dilakukan dengan kaki yang terkuat dan kerap kali tidak tepat pada balok tumpuan, (3) melayang, pada saat melayang siswa tidak dapat mempertahankan posisi tubuh selama mungkin, (4) mendarat, pada saat mendarat siswa jatuh ke belakang. Penelitian ini bertujuan: (1) untuk mengetahui ada tidaknya hubungan antara kecepatan lari dengan hasil lompat jauh pada siswa putra kelas atas SD Negeri 3 Sigli; (2) untuk mengetahui ada tidaknya hubungan antara kekuatan otot tungkai dengan hasil lompat jauh pada siswa putra kelas atas SD Negeri 3 Sigli; (3) untuk mengetahui ada tidaknya hubungan antara kecepatan lari dan kekuatan otot tungkai dengan hasil lompat jauh pada siswa putra kelas atas SD Negeri 3 Sigli tahun pelajaran 2018/2019.

Penelitian ini adalah penelitian korelasional dengan metode survei yang pengambilan datanya dilakukan dengan tes pengukuran. Populasi pada penelitian ini adalah semua siswa putra kelas atas SD Negeri 3 Sigli tahun pelajaran 2018/2019. Populasi pada penelitian ini berjumlah 40 orang siswa putra. Data pada penelitian ini diambil dengan tes yang terdiri dari: tes lari $40 \mathrm{~m}$ untuk mengukur kecepatan; tes lompat jauh tanpa awalan untuk mengukur kekuatan otot tungkai; dan tes lompat jauh untuk mengukur hasil lompat jauh. Analisis untuk menguji hipotesis dilakukan dengan menggunakan teknik analisis korelasi product moment dan analisis regresi berganda; dengan tingkat kepercayaan $5 \%$.
\end{abstract}

Kata Kunci: kecepatan lari, kekuatan otot tungkai, hasil lompat jauh

\section{PENDAHULUAN}

\section{A. Latar Belakang Masalah}

Pendidikan Jasmani Olahraga dan Kesehatan merupakan bagian integral dari pendidikan secara keseluruhan, bertujuan untuk mengembangkan aspek kebugaran jasmani, keterampilan gerak, keterampilan berpikir kritis, keterampilan sosial, penalaran, stabilitas emosional, tindakan moral, aspek pola hidup sehat dan pengenalan lingkungan bersih melalui aktivitas jasmani, olahraga dan kesehatan terpilih yang direncanakan secara sistematis dalam rangka mencapai tujuan pendidikan nasional. Pendidikan Jasmani, Olahraga dan Kesehatan yang diajarkan di sekolah memiliki peranan sangat penting, yaitu memberikan kesempatan kepada peserta didik untuk terlibat langsung dalam berbagai pengalaman belajar melalui aktivitas jasmani, olahraga dan kesehatan yang terpilih yang dilakukan secara sistematis (Permendiknas Nomor 22 Tahun 2006 tentang Standar Isi, halaman 702). 
Pembekalan pengalaman belajar itu diarahkan untuk membina pertumbuhan fisik dan pengembangan psikis yang lebih baik, sekaligus membentuk pola hidup sehat dan bugar sepanjang hayat. Ruang lingkup mata pelajaran Pendidikan Jasmani, Olahraga, dan Kesehatan meliputi berbagai aspek, salah satunya adalah permainan dan olahraga, meliputi: olahraga tradisional, permainan, eksplorasi gerak, keterampilan lokomotor, non-lokomotor, dan manipulatif, atletik, kasti, rounders, kippers, sepak bola, bola basket, bolavoli, tenis meja, tenis lapangan, bulutangkis, dan beladiri, serta aktivitas lainnya, (Permendiknas Nomor 22 Tahun 2006 tentang Standar Isi, halaman 703).

Atletik merupakan cabang olahraga yang tertua dan juga induk dari semua cabang olahraga, yang di dalamnya terdiri dari empat nomor utama yaitu jalan, lari, lompat dan lempar. Dari setiap nomor tersebut terdapat beberapa nomor yang diperlombakan. Untuk nomor lari terdiri dari: lari jarak pendek, jarak menengah, jarak jauh atau marathon, lari gawang, lari sambung, dan lari cross county. Nomor lompat meliputi: lompat jauh, lompat tinggi, lompat jangkit, lompat tinggi galah. Nomor lempar meliputi lempar cakram, lompat jauh, dan lontar martil.

Lompat jauh merupakan salah satu nomor dari cabang atletik yang diajarkan di kelas atas sekolah dasar (SD) yang tertuang dalam Standar Kompetensi (SK) dan Kompetensi Dasar (KD) Permendiknas Nomor 22 Tahun 2006 tentang Standar Isi. Dijabarkan pula dalam Kurikulum Tingkat Satuan Pelajaran (KTSP) dan Silabus SD Negeri 3 Sigli. Standar Kompetensi dan Kompetensi Dasar yang sebagai dasar pembelajaran atletik khususnya lompat jauh dapat dilihat pada tabel 1 di bawah ini. 
Jurnal Sosial Humaniora Sigli (JSH)

p ISSN : 2615-3688

$e$ ISSN : 2716-0270

http://journal.unigha.ac.id/index.php/JSH

Tabel 1. Standar Kompetensi dan Kompetensi Dasar Pembelajaran Atletik

\begin{tabular}{|r|r|l|l|}
\hline No & Kelas & \multicolumn{1}{|c|}{ Standar Kompetensi } & \multicolumn{1}{|c|}{ Kompetensi Dasar } \\
\hline 1 & IV & $\begin{array}{l}\text { Mempraktikkan gerak dasar ke } \\
\text { dalam permainan sederhana dan } \\
\text { olahraga serta nilai-nilai yang } \\
\text { terkandung di dalamnya. }\end{array}$ & $\begin{array}{l}\text { Mempraktikkan gerak dasar } \\
\text { atletik sederhana, serta nilai } \\
\text { semangat, percaya diri dan } \\
\text { disiplin. }\end{array}$ \\
\hline 2 & V & $\begin{array}{l}\text { Mempraktikkan berbagai variasi } \\
\text { gerak dasar ke dalam permainan dan } \\
\text { olahraga dengan peraturan yang } \\
\text { dimodifikasi serta nilai-nilai yang } \\
\text { terkandung di dalamnya. }\end{array}$ & $\begin{array}{l}\text { Mempraktikkan variasi gerak } \\
\text { dasar ke dalam modifikasi } \\
\text { atletik, serta nilai semangat, } \\
\text { sportivitas, percaya diri dan } \\
\text { kejujuran. }\end{array}$ \\
\hline 3 & VI & $\begin{array}{l}\text { Mempraktikkan berbagai gerak dasar } \\
\text { permainan dan olahraga dengan } \\
\text { peraturan yang dimodifikasi, dan } \\
\text { nilai-nilai yang terkandung di } \\
\text { dalamnya. }\end{array}$ & $\begin{array}{l}\text { Mempraktikkan koordinasi } \\
\text { gerak dasar dalam teknik lari, } \\
\text { lempar dan lompat dengan } \\
\text { peraturan yangdimodifikasi, serta } \\
\text { nilai semangat, sportivitas, percaya } \\
\text { diri dan kejujuran. }\end{array}$ \\
\hline
\end{tabular}

Lompat jauh adalah suatu bentuk gerakan melompat mengangkat kaki ke atas, ke depan dalam upaya membawa titik berat badan selama mungkin di udara yang dilakukan dengan cepat dan dengan jalan melakukan tolakan pada satu kaki untuk mencapai jarak yang sejauh-jauhnya (Aip Syaifuddin, 1992: 90), Peningkatan kemampuan lompat jauh dalam pembelajaran pendidikan jasmani siswa sekolah dasar (SD) perlu dilakukan secara intensif agar bisa meraih hasil yang maksimal. Bentuk latihan yang sangat penting dilakukan adalah unsur kecepatan dan kekuatan otot tungkai. Siswa atau atlet yang dapat melakukan gerak secara eksplosif yaitu gerakan yang kuat dan cepat, seperti lompat tinggi, melompat jauh, menendang dan memukul keras, maka dapat dikatakan bahwa siswa tersebut memiliki kemampuan kekuatan atau power yang baik. Hal tersebut ditegaskan oleh Sri Haryono (2008: 32) yang menyatakan bahwa: "Power menyangkut kekuatan dan kecepatan kontraksi otot yang dinamis dan eksplosif serta melibatkan pengerahan kekuatan otot yang maksimal dalam waktu yang secepat mungkin". Sedangkan kecepatan adalah kemampuan seseorang untuk mengerjakan gerakan berkesinambungan dalam bentuk yang sama dalam waktu yang sesingkat-singkatnya, (Sajoto, 1990: 17). Dengan demikian dapat dikatakan bahwa unsur kecepatan dan kekuatan otot tungkai merupakan unsur-unsur fisik yang sangat diperlukan seorang atlet pada saat melakukan lompat jauh.

Kecepatan yang dibutuhkan siswa dalam melakukan lompat jauh adalah kecepatan lari melakukan awalan. Awalan merupakan suatu gerakan yang dilakukan dengan lari cepat secara gradual (sedikit demi sedikit) meningkat, langkah terakhir dalam awalan lari pelompat bersiap merubah kecepatan horizontal menjadi kecepatan vertikal pada saat menumpu, lutut harus diangkat sedikit lebih tinggi dari pada dalam suatu langkah lari sprint yang normal guna menjamin atau mempertahankan tubuh pelompat ada dalam posisi tegak (Eddy Purnomo dan Dapan, 2011: 94).

Hasil lompat jauh tidak hanya 
ditentukan oleh kecepatan lari awalan tetapi ditentukan pula oleh kekuatan otot tungkai. Kekuatan otot merupakan tenaga/gaya atau tegangan yang dapat dihasilkan otot atau sekelompok otot pada suatu kontraksi maksimal (Pusat Kesegaran Jasmani dan Rekreasi, 1997: 5). Teknik awalan dan tolakan merupakan dua unsur pokok yang menentukan untuk mencapai jarak yang sejauh-jauhnya. Oleh karena itu, pelompat harus benar- benar melakukannya dengan kuat, cepat dan tepat. Dan untuk memperoleh hasil yang maksimal dalam lompat jauh khususnya pada saat melakukan tolakan, maka seorang olahragawan harus memperhatikan gerakan saat bertolak.

Pembelajaran atletik nomor lompat jauh di sekolah dasar cenderung membelajarkan penguasaan teknik dan prestasi, sehingga banyak siswa yang tidak berminat pada cabang olahraga lompat jauh. Akibat tidak berminat banyak siswa enggan untuk mengikuti pembelajaran pada cabang ini. Siswa tidak pada tempatnya bila mereka dilatih untuk mencapai prestasi tinggi dalam olahraga tetapi sebaliknya mereka harus dibimbing sesuai dengan kemampuannya. Dalam pengajaran Penjaskesrek di sekolah dasar sebaiknya disesuaikan dengan tingkat kemampuan siswa baik ditinjau dari segi fisik maupun ditinjau dari segi mental.

Di samping itu, sarana dan prasarana dimungkinkan juga sebagai salah satu sebab hasil belajar atletik khususnya materi lompat jauh menjadi kurang. Hal lain, yang menentukan hasil lompatan dalam lompat jauh adalah faktor kondisi fisik, diantaranya adalah kecepatan lari dan kekuatan otot tungkai. Latihan kecepatan lari dan kekuatan otot tungkai yang dilakukan secara intensif, terarah dan teratur dapat mencapai hasil lompatan dalam lompat jauh secara maksimal.

Kenyataan yang ada pada siswa putra kelas atas SD Negeri 3 Sigli belum menunjukkan hasil belajar yang maksimal atau dapat dikatakan hasil lompatan dalam lompat jauh siswa putra kelas atas kurang. Pencapaian hasil lompatan dalam lompat jauh yang kurang tersebut disebabkan karena beberapa faktor, antara lain: minat siswa yang rendah, sarana dan prasarana yang tidak memadai, dan kesalahan-kesalahan yang sering dilakukan pada saat melakukan langkah-langkah lompat jauh. Faktor minat yang tampak saat pembelajaran antara lain: siswa tidak tertarik dengan pembelajaran lompat jauh. Ketidaktertarikan ini dimungkinkan karena pembelajaran lompat jauh dilakukan dengan cara konvensional dengan mengedepankan peranan guru secara totalitas. Sehingga proses pembelajaran yang terjadi bersifat komunikasi satu arah, siswa pasif menunggu instruksi dari guru. Pembelajaran konvensional yang dilaksanakan oleh guru mengakibatkan siswa tidak antusias mengikuti pembelajaran, sehingga kemampuan lompat jauh siswa menjadi rendah. Faktor lain yang mengakibatkan kemampuan lompat jauh rendah adalah sarana dan prasarana yang dimiliki sekolah. Pembelajaran lompat jauh dilakukan di halaman sekolah yang sempit dan hanya memiliki satu buah bak pasir yang berukuran lebar 1 meter dan panjang 4 meter.

\section{B. Identifikasi Masalah}

Berdasarkan latar belakang masalah di atas, maka dapat diidentifikasi beberapa masalah sebagai berikut:

1. Keterbatasan sarana dan prasarana menjadi salah satu penghambat keberhasilan Penjaskesrek khususnya materi atletik nomor lompat jauh.

2. Pembelajaran materi atletik khususnya nomor lompat jauh kurang diminati oleh siswa.

3. Belum diketahui hubungan antara kecepatan lari dengan hasil lompat jauh pada siswa putra kelas atas SD Negeri 3 Sigli tahun pelajaran 2018/2019.

4. Belun diketahui hubungan antara kekuatan otot tungkai dengan hasil lompat jauh pada siswa putra kelas atas SD Negeri 3 Sigli, tahun pelajaran 2018/2019.

5. Belum diketahui hubungan antara kecepatan lari dan kekuatan otot tungkai dengan hasil lompat jauh pada siswa putra kelas atas SD Negeri 3 Sigli, tahun pelajaran 2018/2019.

\section{METODE PENELITIAN}

\section{A.Desain Penelitian}


Penelitian ini merupakan jenis penelitian korelasional dengan metode survei yang pengambilan datanya dilakukan dengan tes dan pengukuran. Dalam penelitian ini, peneliti berusaha menghubungkan variabel satu dengan variabel yang lain yaitu variabel terikat dan variabel bebas. Variabel terikat dalam penelitian ini adalah kecepatan lari (X1) dan kekuatan otot tungkai (X2), sedangkan variabel bebasnya yaitu lompat jauh (Y). Adapun desain penelitian sebagai berikut.

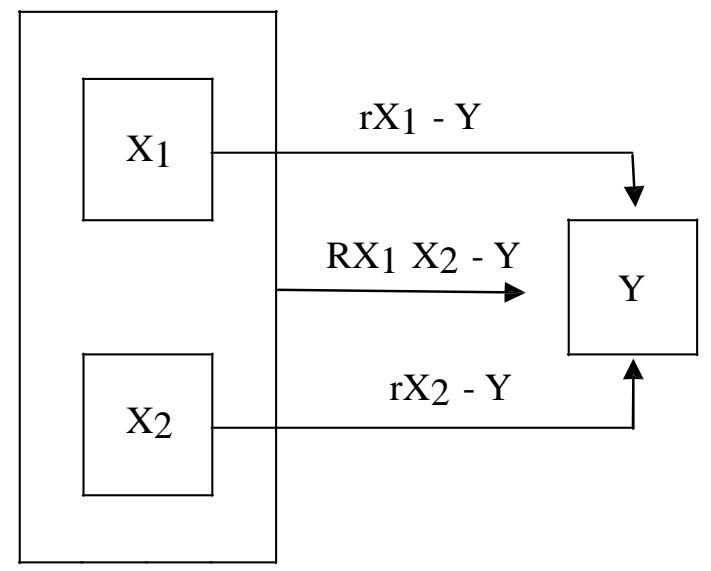

Gambar 5. Desain Penelitian

Keterangan:

1. Variabel $\mathrm{X}_{1}$ adalah kecepatan lari.

2. Variabel $\mathrm{X}_{2}$ adalah kekuatan otot tungkai.

3. Variabel Y adalah lompat jauh.

1. Uji Persyaratan Analisis

Uji normalitas dimaksudkan untuk mengetahui apakah data hasil penelitian berdistribusi normal atau tidak. Apabila data yang terjaring berdistribusi normal, maka analisis untuk menguji

\section{Pengujian Hipotesis}

Hipotesis merupakan jawaban sementara terhadap rumusan masalah penelitian. Untuk membuktikan kebenaran hipotesis yang telah dikemukakan, maka dilakukan suatu pengujian hipotesis. Pengujian hipotesis dilakukan setelah dilakukannya pengujian analisis. Dalam penelitian ini yang membahas tentang hubungan antara beberapa variabel bebas dan terikat, maka termasuk dalam kriteria hipotesis asosiatif.

Data penelitian ini merupakan data empirik atau lapangan. Sedangkan menurut ciri penggolongannya merupakan data interval, karena dalam perjenjangannya jarak perskalaan sama. Penelitian ini merupakan data kuantitatif sehingga analisisnya menggunakan teknik analisis kuantitatif dengan menggunakan metode statistik.

Pengolahan data dan analisis statistik dalam rangka pengujian hipotesis dilakukan setelah adanya uji persyaratan analisis, supaya kesimpulan yang ditarik memenuhi syarat, adapun persyaratan untuk analisis regresi yaitu data diambil secara acak, normalitas sebaran, linieritas hubungan antara variabel $\mathrm{Y}$ dan $X$, serta tidak adanya interkorelasi antar variabel bebas. Selanjutnya mengenai hal tersebut Sutrisno Hadi (2005: 66), mengemukakan pendapatnya persyaratan dalam analisis regresi ganda.

. Sampel yang digunakan dalam penyelidikan harus yang diambil secara random.

b. Hubungan antara variabel $\mathrm{X}$ dan variabel $\mathrm{Y}$ merupakan garis lurus atau hubungan linier.

c. Bentuk distribusi variabel $\mathrm{X}$ dan variabel Y dalam populasi adalah atau 
mendekati distribusi normal.

Selanjutnya dalam rangka pengujian hipotesis pertama untuk mengetahui hubungan kecepatan lari dengan kemampuan lompat jauh digunakan teknik korelasi product moment. Begitu pula untuk mengetahui hubungan power tungkai dengan kemampuan lompat jauh (hipotesis kedua) digunakan teknik korelasi product moment. Formula dari teknik korelasi product moment.

\section{HASIL PENELITIAN DAN PEMBAHASAN}

\section{a. Hubungan Antara Kecepatan Lari dengan Hasil Lompat Jauh}

Pada bagian ini secara spesifik dapat dihipotesiskan, sebagai berikut: "ada hubungan yang signifikan antara kecepatan lari dengan hasil lompat jauh pada siswa putra kelas atas SD Negeri 3 Sigli". Analisis yang digunakan untuk menguji hipotesis tersebut adalah korelasi product moment (rXY). Berdasarkan tabel

5 tersebut di atas, yang dianalisis dengan bantuan software komputer,

diperoleh koefisien korelasi product moment antara kecepatan lari $\left(\mathrm{X}_{1}\right)$

dengan hasil lompat jauh (Y) sebesar= $-0,543$

Dikarenakan p lebih kecil dari alpha (taraf signifikansi) yang ditentukan yaitu 5\%; maka koefisien korelasi product moment tersebut signifikan. Hal ini berarti bahwa hipotesis yang menyatakan ada hubungan yang signifikan antara kecepatan lari dengan hasil lompat jauh pada siswa putra kelas atas SD Negeri 3 Sigli terbukti kebenarannya.

Dengan demikian dapat disimpulkan bahwa ada hubungan yang signifikan antara kecepatan lari dengan hasil lompat jauh pada siswa putra kelas atas SD Negeri 3 Sigli. Hubungan yang signifikan ini berarti bahwa semakin cepat lari siswa, semakin baik pula hasil lompat jauh siswa putra kelas atas SD Negeri 3 Sigli; dan sebaliknya semakin rendah (lambat) kecepatan lari siswa, semakin kurang baik pula hasil lompat jauh siswa putra kelas atas SD Negeri 3 Sigli.

\section{b. Hubungan Antara Kekuatan Otot Tungkai dengan Hasil Lompat Jauh}

Pada bagian ini secara spesifik dapat dihipotesiskan, sebagai berikut: "ada hubungan yang signifikan antara kekuatan otot tungkai dengan hasil lompat jauh pada siswa putra kelas atas SD Negeri 3 Sigli, Kecamatan Puring, Kabupaten Kebumen". Analisis yang digunakan untuk menguji hipotesis tersebut adalah korelasi product moment (rXY). Berdasarkan tabel 5 tersebut di atas, yang dianalisis dengan bantuan software komputer, diperoleh koefisien korelasi product moment antara kekuatan otot tungkai $\left(\mathrm{X}_{2}\right)$ dengan hasil lompat jauh $(\mathrm{Y})$ sebesar $=0,626$

dengan $\mathrm{p}=0,000$. Dikarenakan $\mathrm{p}$ lebih kecil dari alpha (taraf signifikansi) yang ditentukan yaitu 5\%; maka koefisien korelasi product moment tersebut signifikan. Hal ini berarti bahwa hipotesis yang menyatakan ada hubungan yang signifikan antara kekuatan otot tungkai dengan hasil lompat jauh pada siswa putra kelas atas SD Negeri 3 Sigli terbukti kebenarannya.

Dengan demikian dapat disimpulkan bahwa ada hubungan yang signifikan antara kekuatan otot tungkai dengan hasil lompat jauh pada siswa putra kelas atas SD Negeri 3 Sigli, Kecamatan Puring, Kabupaten Kebumen. Hubungan yang signifikan ini berarti bahwa semakin baik kekuatan otot tungkai, semakin baik pula hasil lompat jauh siswa putra kelas atas SD Negeri 3 Sigli; dan sebaliknya semakin kurang baik kekuatan otot tungkai, semakin kurang baik pula hasil lompat jauh pada siswa putra kelas atas SD Negeri 3 Sigli.

\section{c. Hubungan Antara Kecepatan Lari dan Kekuatan Otot Tungkai dengan Hasil Lompat Jauh pada Siswa Putra SD Negeri 3 Sigli}

Pada bagian ini dapat dirumuskan hipotesis bahwa: "Ada hubungan yang signifikan antara kecepatan lari dan kekuatan otot tungkai dengan hasil lompat jauh pada siswa putra kelas atas SD Negeri 3 Sigli, Kecamatan Puring, Kabupaten Kebumen". Analisis 
Jurnal Sosial Humaniora Sigli (JSH)

p ISSN : 2615-3688

$e$ ISSN : 2716-0270

http://journal.unigha.ac.id/index.php/JSH

yang digunakan untuk menguji hipotesis ini adalah korelasi ganda (multiple correlation) dan untuk mengetahui signifikansinya digunakan analisis regresi ganda.

Analisis regresi pada penelitian ini digunakan bantuan software komputer

Berdasarkan tabel 5 tersebut di atas, diketahui bahwa koefisien korelasi ganda $\mathrm{R}_{\mathrm{y}}(1,2)$ adalah 0,677; dan untuk mengetahui apakah koefisien korelasi ganda tersebut signifikan atau tidak, selanjutnya dianalisis dengan analisis regresi ganda yang menghasilkan Fregresi. Dari hasil perhitungan dengan bantuan software komputer diperoleh Fregresi sebesar 15.905, seperti terlihat pada tabel 7 ringkasan analisis regresi berikut ini. dengan program SPS 2005 (Seri Program Statistik) edisi Sutrisno Hadi dan Yuni Pamardiningsih tahun 2005; hasil perhitungan dapat dilihat pada tabel 6 berikut ini. 
Jurnal Sosial Humaniora Sigli (JSH)

p ISSN : 2615-3688

$e$ ISSN : 2716-0270

http://journal.unigha.ac.id/index.php/JSH

Tabel 7. Ringkasan Analisis Regresi Ganda antara Prediktor $\mathrm{X}_{1}$, dan $\mathrm{X}_{2}$, terhadap Kriterium Y

\begin{tabular}{|c|c|r|r|r|r|}
\hline $\begin{array}{c}\text { Sumber } \\
\text { Variasi }\end{array}$ & JK & \multicolumn{1}{c|}{$\mathrm{db}$} & \multicolumn{1}{c|}{ RK } & Freg & $\mathrm{p}$ \\
\hline Regresi & 18940.98 & 1 & 18940.979 & 15.905 & 0,000 \\
Residu & 45254.62 & 38 & 1190.911 & & \\
\hline Total & 64195.60 & 39 & --- & --- & --- \\
\hline
\end{tabular}

Berdasarkan tabel 7 tersebut di atas, dapat dilihat harga $F_{\text {reg }}$ hasil sebesar 15,905 dengan $p$ (sig.) sebesar 0,000. Ternyata didapatkan $\mathrm{p}$ kurang dari taraf signifikansi yang ditentukan yaitu 5\%; maka hipotesis yang diajukan pada penelitian ini terbukti kebenarannya, dan disimpulkan ada hubungan yang signifikan antara kecepatan lari dan kekuatan otot tungkai dengan hasil lompat jauh pada siswa putra kelas atas SD Negeri 3 Sigli. besarnya koefisien determinasi $\left(\mathrm{R}^{2}\right)=0,458$. Hal ini berarti bahwa hasil lompat jauh pada siswa putra kelas atas SD Negeri 3 Sigli mampu dijelaskan oleh kecepatan lari dan kekuatan otot tungkai sebesar 0,458 atau $45,8 \%$. Adapun sumbangan relatif (SR\%) dan sumbangan efektif (SE\%) pada masingmasing prediktor disajikan tabel 8 berikut ini.

Berdasarkan hasil analisis di atas, diperoleh

Tabel 8. Ringkasan Bobot Sumbangan Relatif dan Sumbangan Efektif Prediktor Terhadap Kriterium

\begin{tabular}{|c|c|c|}
\hline \multirow{2}{*}{ Prediktor } & \multicolumn{2}{|c|}{ Sumbangan (\%) } \\
\cline { 2 - 3 } 1. Kecepatan Lari (X1) & Relatif (SR) & Efektif (SE) \\
2. Kekuatan Otot Tungkai (X2) & 64,386 & 16,210 \\
$\begin{array}{c}\text { 3. Faktor Lain (daya ledak, } \\
\text { ketepatan, kelenturan, dan } \\
\text { koordinasi) }\end{array}$ & - & 29,599 \\
\hline Total & 100 & 54,191 \\
\hline
\end{tabular}


Berdasarkan tabel 8 tersebut di atas, diketahui bahwa prediktor atau variabel bebas kecepatan lari (X1) memberikan sumbangan efektif sebesar 16,210\%; sedangkan kekuatan otot tungkai $\left(\mathrm{X}_{2}\right)$ mampu memberikan sumbangan efektif sebesar $29,599 \%$. Secara bersama-sama kedua prediktor atau variabel bebas tersebut memberikan sumbangan efektif sebesar 45,809\% terhadap hasil lompat jauh. Sedangkan sisanya sebesar $54,191 \%$ dipengaruhi oleh faktor-faktor lainnya. Faktor-faktor tersebut antara lain: daya ledak, ketepatan, kelenturan, dan koordinasi.

Analisis regresi menghasilkan persamaan garis regresi dengan angka kasar, sebagai berikut:

$$
\begin{aligned}
& \hat{Y}= \\
& 1,113 X_{2}
\end{aligned} \quad 5266,110+-20,606 X_{1}+
$$

Persamaan regresi tersebut di atas, berarti bahwa setiap kecepatan lari berubah satu unit angka kasar (meningkat/menurun), maka hasil lompat jauh pada siswa putra kelas atas SD Negeri 3 Sigli akan berubah sebesar -20,606; dengan asumsi bahwa variabel bebas lain tidak berubah atau tetap. Apabila kekuatan otot tungkai satu unit angka kasar, maka hasil lompat jauh pada siswa putra kelas atas SD Negeri 3 Sigli, Kecamatan Puring, Kabupaten Kebumen akan berubah sebesar 1,113; dengan asumsi variabel bebas lain tidak berubah.

\section{KESIMPULAN DAN SARAN}

\section{A. Kesimpulan}

Berdasarkan hasil penelitian dan pembahasan yang telah dilakukan, kesimpulan yang dapat diambil pada penelitian ini adalah sebagai berikut:

1. Ada hubungan yang signifikan antara kecepatan lari dengan hasil lompat jauh pada siswa putra kelas atas SD Negeri 3 Sigli tahun pelajaran 2018/2019.

2. Ada hubungan yang signifikan antara kekuatan otot tungkai dengan hasil lompat jauh pada siswa putra kelas atas SD Negeri 3 Sigli, Kecamatan Puring, Kabupaten Kebumen, tahun pelajaran 2018/2019.

3. Ada hubungan yang signifikan antara kecepatan lari dan kekuatan otot tungkai secara bersama-sama dengan hasil lompat jauh pada siswa putra kelas atas SD Negeri 3 Sigli tahun pelajaran 2018/2019. Kecepatan lari memberikan kontribusi efektif sebesar 16,210\%; kekuatan otot tungkai memberikan kontribusi efektif sebesar $29,599 \%$ terhadap hasil lompat jauh pada siswa putra kelas atas SD Negeri 3 Sigli, Kecamatan Puring, Kabupaten Kebumen tahun pelajaran 2018/2019. Dengan demikian kecepatan lari dan kekuatan otot tungkai secara bersama-sama memberikan kontribusi efektif sebesar 45,809\% terhadap hasil lompat jauh pada siswa putra kelas atas SD Negeri 3 Sigli tahun pelajaran 2018/2019.

\section{B. Keterbatasan Hasil Penelitian}

Peneliti sudah berusaha keras memenuhi segala ketentuan yang dipersyaratkan, bukan berarti penelitian ini tanpa kelemahan dan kekurangan. Beberapa kelemahan dan kekurangan yang dapat dikemukakan, antara lain:

1. Peneliti tidak mengontrol aktivitas yang dilakukan subjek sebelum pengambilan data.

2. Proses pengambilan data tidak dilaksanakan di stadion yang memenuhi standar prasarana yang memadahi, tetapi dilaksanakan di sekitar sekolah yang hanya mempunyai prasarana yang terbatas.

3. Sampel penelitian yang digunakan kurang luas, karena hanya mencakup satu sekolah saja, sehingga untuk diaplikasikan pada lingkup yang luas masih perlu dilakukan pengkajian ulang.

\section{Implikasi Hasil Penelitian}

Dengan diketahuinya hubungan antara 
kecepatan lari dan kekuatan otot tungkai terhadap hasil lompat jauh dapat gambaran sebagai acuan bahwa hasil lompat jauh dibutuhkan kecepatan dan kekuatan otot tungkai. Dari dua item itu, yaitu kecepatan lari dan kekuatan otot tungkai memberi sumbangan terhadap hasil lompat jauh. Sehingga hasil penelitian ini dapat memberi masukan bahwa sebelum melakukan pembelajaran lompat jauh, hal yang perlu dilakukan adalah memberikan pembelajaran yang bertujuan untuk meningkatkan kecepatan lari dan kekuatan otot tungkai terlebih dahulu.

\section{Saran-Saran}

Berdasarkan kesimpulan tersebut di atas, peneliti memberi saran-saran sebagai berikut:

1. Bagi Sekolah Sekolah hendaknya memberikan ruang dan waktu bagi guru Penjaskesrek untuk lebih mengintensifkan proses pembelajaran sesuai dengan karakteristik siswa, dan tidak menekan guru Penjaskesrek agar pembelajaran Penjaskesrek menghasilkan prestasi tinggi dalam bidang olahraga, dalam hal ini lompat jauh. Di samping itu, sekolah hendaknya melengkapi sarana dan prasarana olahraga agar pembelajaran dapat mencapai tujuan yang diharapkan.

2. Bagi Guru Penjaskesrek Hendaknya dalam mengajar lompat jauh terlebih dahulu menekankan pada kecepatan lari dan kekuatan otot tungkai, sebab kecepatan lari dan kekuatan otot tungkai mempengaruhi hasil lompatan.

3. Bagi Siswa Apabila guru Penjaskesrek memberikan pembelajaran hendaknya mengikuti petunjuk dan arahan yang diberikan guru.

4. Bagi Peneliti Selanjutnya Apabila hendak melakukan penelitian sejenis, hendaknya menggunakan hasil penelitian ini sebagai bahan referensi sehingga dapat memperoleh hasil yang lebih sempurna.

\section{DAFTAR PUSTAKA}

Adang Suherman. (2003) Dasar-Dasar
Penjaskes. Deparemen Pendidikan Nasional Direktorat Jenderal Pendidikan Nasional dan Menengah Bagian Proyek Penataran Guru SLTP Setara D-III.

Adang Suherman dan Agus Mahendra. (2001). Menuju Perkembangan Menyeluruh. Jakarta: Ditjen Olahraga.

Ballesteros. (1993). Pedoman Latihan Dasar Atletik. (Terjemahan). Jakarta: PB. PASI.

Depdiknas. (2003). Tes Kesegaran Jasmani Indonesia Untuk Anak Umur 10-12 Tahun. Jakarta: Pusat Kesegaran Jasmani dan Rekreasi.

Desmita. (2010). Psikologi Perkembangan. Bandung: PT Remaja Rosdakarya. Djoko Pekik Irianto. (2004). Panduan Latihan Kebugaran yang Efektif dan Aman. Yogyakarta: Lukman offset.

Eddy Purnomo dan Dapan. (2011). DasarDasar Gerak Atletik. Yogyakarta: Alfamedia.

Eka Putut Haryanto. (2010). Hubungan antara Kecepatan Lari dan Lompat Jauh tanpa Awalan dengan Kemampuan Lompat Jauh Gaya Jongkok Siswa Putra Kelas VIII SMP Negeri 1 Kuwarasan Kabupaten Kebumen. Skripsi. Yogyakarta: FIK UNY.

Harsuki dan Soewatini Elias. (2003). Perkembangan Olah Raga Terkini Kajian Para Pakar. Jakarta : Rajagrafindo Persada.

Ruchayah. (2010). Hubungan antara Lari Cepat 60 Meter dengan Hasil Belajar Lompat Jauh Gaya Jongkok Siswa Putra Kelas IV-V SD Negeri 2 Kalierang Kecamatan Selomerto Kabupaten Wonosobo Tahun Ajaran 2009/2010. Skripsi. Yogyakarta: FIK UNY.

Rusli Lutan. (2001). Menuju Sehat Bugar. Direktorat Jenderal Pendidikan Dasar Menengah dan Olahraga Jakarta: Depdiknas.

Sadoso Sumosardjuno. (1997). Pengetahuan praktis kesehatan dalam olahraga. Jakarta: PT 
Jurnal Sosial Humaniora Sigli (JSH)

p ISSN : 2615-3688

$e$ ISSN : 2716-0270

http://journal.unigha.ac.id/index.php/JSH

Gramedia Pustaka Utama.

Soegito dkk. (1993). Materi Pokok

Pendidikan Atletik. Jakarta:

Departemen Pendidikan dan

Kebudayaan.

Sajoto. (1990). Peningkatan dan

Pembinaan Kekuatan Kondisi

Fisik Dalam Olahraga. Bandung:

Dahara Prize.

Siti Rahayu Haditono. (2006). Psikologi Perkembangan. Yogyakarta: Gadjah Mada University Press.

Sri Haryono. (2008). Buku Pedoman Praktek Laboratorium Mata Kuliah Tes dan Pengukuran

. (2002). Metodologi Research Jilid III. Yogyakarta: Andi Offset.

. (2004). Metodologi Research Jilid 3. Yogyakarta : Andi Offset.

Sutrisno Hadi dan Yuni Pamardiningsih. (2005). Petunjuk Penggunaan Program SPS (Seri Program Statistik). Yogyakarta: Universitas Gadjah Mada. 